\title{
Gross and net primary production: closing the gap between concepts and measurements
}

\author{
John Beardall ${ }^{1, *}$, Sven Ihnken ${ }^{1}$, Antonietta Quigg ${ }^{2}$ \\ ${ }^{1}$ School of Biological Sciences, Monash University, Clayton, Victoria 3800, Australia \\ ${ }^{2}$ Departments of Marine Biology and Oceanography, Texas A \& M University at Galveston, Galveston, Texas 77551, USA
}

\begin{abstract}
We are living at a time when accurate knowledge of the magnitude of the drawdown of inorganic carbon by autotrophic metabolism is especially crucial to our understanding of global carbon cycling and the functioning of the global ecosystem. Since algae contribute approximately half of the planet's annual primary productivity, understanding the processes contributing to the net assimilation of $\mathrm{CO}_{2}$ is critical. In this paper, we briefly discuss the range of approaches to measurements of aquatic photosynthesis that have been used, including more recent developments such as fluorescence and stable isotope studies, and whether these provide data that reflect net or gross productivity. We then consider the range of processes that run counter to photosynthetic carbon assimilation, with emphasis on respiration (and its measurement) and excretion of dissolved organic carbon, and how these affect our estimates of net primary production. We conclude by briefly assessing how future changes in global climate might impact not just overall primary productivity, but also the balance between net and gross carbon assimilation.
\end{abstract}

KEY WORDS: Primary productivity - Photosynthesis - Respiration - Algae - Protein turnover • Homeostasis · Fluorescence

Resale or republication not permitted without written consent of the publisher

\section{INTRODUCTION}

Marine ecosystems account for $50 \%$ of the 111 to $117 \mathrm{Pg}$ carbon assimilated annually across our planet (Falkowski \& Raven 2007). Of this, the majority ( 75\%) is assimilated by phytoplankton in the open ocean, and the balance is assimilated by algae and seagrasses that inhabit the coastal regions. In an era when atmospheric $\mathrm{CO}_{2}$ levels are rising rapidly due to human activities, understanding the role of phototrophs in the global carbon cycle is arguably becoming more important than ever, and the question of how to accurately measure the primary productivity of these organisms is critical in determining their potential role in carbon drawdown and cycling.

The simplest approach to determining primary production is to measure the rate at which primary producers accrue biomass. However, this can be time consuming and is affected by a range of processes discussed briefly below. Nonetheless, there are a number of processes involved in photosynthesis, measure- ment of which can provide a proxy of primary productivity. Perhaps the most obvious of these is the assimilation of inorganic carbon into organic matter. In marine systems, this inorganic carbon takes the form of $\mathrm{CO}_{2}$ and/or bicarbonate dissolved in seawater as follows:

$$
\begin{array}{rlrl}
\mathrm{CO}_{2}(\mathrm{aq}) \leftrightarrow \mathrm{H}_{2} \mathrm{CO}_{3} \leftrightarrow \mathrm{HCO}_{3}{ }^{-}+\mathrm{H}^{+} & \leftrightarrow \mathrm{CO}_{3}{ }^{2-} \\
\text { pKa } & =5.85 & \mathrm{pKa} & =8.92
\end{array}
$$

The $\mathrm{CO}_{2}$ in seawater is (ideally) in equilibrium with that in the atmosphere, but represents only a small fraction of the total carbon available for assimilation, with bicarbonate being the major inorganic carbon source. The carbonate ion is not available for photosynthesis. Thus, we can measure primary productivity by detecting the amount of carbon taken up by cells.

For nearly $60 \mathrm{yr}$, scientists have been measuring the uptake of a tracer, supplied as radioactive ${ }^{14} \mathrm{C}$ (Steeman Nielsen 1952, Johnston \& Raven 1990, Thomas \& Wiencke 1991, Williams et al. 2002), and more recently using the stable isotope ${ }^{13} \mathrm{C}$ (Miller \& Dunton 2007), 
into cells. Of the ${ }^{14} \mathrm{C}$ approach, Longhurst et al. (1995) wrote 'Rarely, in fact, can a technique have been so persistently criticized, but so consistently used.' Williams et al. (2002) comprehensively reviewed $50 \mathrm{yr}$ of progress since the original paper of Steeman Nielsen (1952) and addressed important questions such as the uncertainty associated with whether the ${ }^{14} \mathrm{C}$-derived primary productivity rate is closer to net or gross primary productivity and other fundamental aspects of this technique and its application. The issue of gross vs. net productivity and the ecological implications of their measurements are discussed thoroughly by Williams (1993).

Another in vitro technique involves the use of ${ }^{18} \mathrm{O}$ labelled water, rather than ${ }^{14} \mathrm{C}$-labelled $\mathrm{CO}_{2}$, to measure gross primary productivity, which is sometimes done concurrently with ${ }^{14} \mathrm{C}$-derived primary productivity measurements (Grande et al. 1989a, Bender et al. 1999). Differences in results between the 2 methods (1.5 to 2-fold) are attributed to the Mehler reaction, photorespiration, and/or $\mathrm{DO}^{14} \mathrm{C}$ recycling (Laws et al. 2000). Others have made use of an anomaly in the ${ }^{17} \mathrm{O} /{ }^{16} \mathrm{O}$ ratio in atmospheric $\mathrm{O}_{2}$ to estimate gross productivity rates in the ocean (e.g. Luz \& Barkan 2000 ), or the $\delta^{18} \mathrm{O}$ of dissolved $\mathrm{O}_{2}$ in surface waters as a tracer of biological productivity (e.g. Quay et al. 1993).

Non-isotopic measures based on direct measurements of gas exchange by infrared gas analysis (Johnston \& Raven 1986) are less applicable in high $\mathrm{pH}$ and marine systems, but can be useful in lower $\mathrm{pH}$ environments. Photoacoustics is based on the principle that some of the energy absorbed by photosynthetic organisms is emitted not as fluorescence, but as heat. A pulse of light will then give a pulse of heat, which will cause expansion in the medium and a consequent pressure wave. This pressure wave can be picked up by sensitive microphones (photoacoustic detectors). This approach has been used in higher plant photosynthesis (Herbert et al. 2000) as well as in algae (Dubinsky et al. 1998, Pinchasov et al. 2007).

Photosynthesis can also be measured as the rate of energy transduction and electron transport that are used to drive NADP reduction and the phosphorylation of ADP; these are detected as changes in cellular fluorescence. Electron transport in oxygenic photoautotrophs involves the withdrawal of electrons and protons from water (e.g. see Quigg et al. 2006), leading to $\mathrm{O}_{2}$ evolution, the latter process being commonly measured as an index of electron transport rates (ETRs). The harvesting of absorbed light energy in photosynthesis is never completely efficient. Fluorescence is essentially a by-product of light harvesting by chlorophyll in antenna regions of the chloroplast. When more light is absorbed than can be used to do photochemical 'work' or is dissipated by 'non-photochemical quenching processes' (e.g. the xanthophyll cycle), energy is dissipated by emission as heat, or as light of a slightly longer wavelength than was used for excitation, i.e. fluorescence. Since the fates of energy generated via chemical work, fluorescence or heat are competitive, measurements of fluorescence output can give an indication of the rates of chemical work, which is equivalent to rates of energy transduction and electron transport. Fluorescence based measurement systems include tools such as pulse amplitude modulated (PAM) fluorometry, fast repetition rate fluorometry (FRRF) and, more recently, fast induction and relaxation fluorometry (FIRe).

While many of the above methods involve in vitro incubations, 2 in situ techniques have been used with greater frequency in recent decades to estimate primary productivity. The first involves measurement of the naturally occurring isotopic composition of dissolved $\mathrm{O}_{2}$ and the ratio of dissolved $\mathrm{O}_{2}$ to argon gas $\left(\mathrm{O}_{2} / \mathrm{Ar}\right)$ in the mixed layer (Luz \& Barkan 2000). This method has the notable advantage of yielding estimates of gross primary productivity and net community production. The second method involves the use of FRRF to obtain instantaneous measurements of water column in situ fluorescence, which are then used to estimate ETR between photosystems (PS) II and I (Kolber et al. 1998). For macroalgae and seagrasses, a DIVING-PAM is similarly employed (Beer et al. 1998, Beer \& Axelsson 2004, Quigg et al. 2008). However, in all cases, the accurate conversion of fluorescence-measured ETRs to primary productivity is still not straightforward. This is an area of active discussion in the scientific community.

\section{CORRESPONDENCE BETWEEN TECHNIQUES FOR MEASURING PRIMARY PRODUCTIVITY}

Generally good agreement exists between fluorescence estimates of ETR and $\mathrm{O}_{2}$ based measurements, but other processes can have an influence. Beer et al. (1998) found good agreement between $\mathrm{O}_{2}$ evolution and fluorescence determined ETRs in seagrasses. Departures from linearity that occurred at high irradiance were ascribed to photorespiration by Beer et al. (1998). However, in other studies using tropical Ulva species, similar departures could not be explained by photorespiratory activity (Carr \& Bjork 2003). Longstaff et al. (2002) showed good agreement between the 2 approaches at low- to mid-levels of irradiance for Ulva lactuca, but departures from linearity again occurred at high irradiances. Similar data were obtained by Figueroa et al. 2003 for Ulva and Porphyra and by Hanelt \& Nultsch (1995) for Palmaria. 
The deviations from strictly linear correlations seem to occur under stress conditions such as high photon flux or nutrient limitation (Gordillo et al. 2001, Longstaff et al. 2002, Beer \& Axelsson 2004). Insufficient caution in common laboratory experiments can also add significant methodical errors. For example, by simply changing the medium during photosynthesis vs. irradiance (P-I) response curve measurements, a curvilinear relationship between ETR and $\mathrm{O}_{2}$ evolution was corrected to a linear correlation (Silva \& Santos 2004). In situ measurements of microphytobenthos showed both linear and curvilinear relations between ETR and carbon fixation at various field sites (Barranguet \& Kromkamp 2000). Again, differences in nutrient supply might cause different energy demand patterns, leading to deviations in the stoichiometry between electrons transported and carbon fixed. Kroon \& Thoms (2006) describe an integrative model that accounts for nutrient status and acclimation of the photosynthetic energy output. Franklin \& Badger (2001) showed reasonable correlation between fluorescence determined ETR and gross $\mathrm{O}_{2}$ evolution based on ${ }^{18} \mathrm{O}$ studies, except when algae were exposed to very high light or starved of inorganic carbon (as a sink for electron flow). Such departures from linearity were explained by Franklin \& Badger (2001) to be associated with alternative energy sinks such as the Mehler reaction, or with enhanced 'dark' respiratory processes running counter to $\mathrm{O}_{2}$ evolution. These are discussed below.

\section{Cyclic electron flow in PSII}

In primary production measurements simultaneously employing fluorescence and $\mathrm{O}_{2}$ exchange, a curvilinear relationship has been reported at high photon fluxes (Gordillo et al. 2001, Longstaff et al. 2002, Beer \& Axelsson 2004). While various mechanisms might be responsible for $\mathrm{O}_{2}$ deviation from potential $\mathrm{O}_{2}$ production rates in linear electron transport, cyclic electron flow within PSII might lead to artificially high ETRs in PSII during high light events. In this case, $\mathrm{O}_{2}$ production might represent 'true' linear ETRs, while fluorescence based measurements might detect elevated electron flow, possibly due to cyclic electron flow through PSII. This type of electron looping in PSII acts as a photoprotective mechanism in events of decreased linear electron transport capacity (Prasil et al. 1996, Miyake \& Yokota 2001). In many cases, high light intensities induce limitations in $\mathrm{CO}_{2}$ fixation, causing product back pressure to the photosynthetic unit. Primary production rates under limitation of some sort (e.g. nutrient limitation) will reduce photosynthetic efficiency in a similar way. Activation of cyclic electron flow in PSII might mimic high photosynthetic competence, although linear ETRs might be lower. Thus, $\mathrm{P} 60^{+}$states in PSII are reduced by electron donation, and by accepting proteins involved in cyclic electron looping. Contributing proteins appear to be P680, plastoquinone, Cyt b-559 and Chl z (Arnon \& Tang 1988, Krieger et al. 1992, Kruk \& Strzalka 2001), although this pathway is still under discussion (Miyake \& Okamura 2003). The principle of energy dissipation is not elucidated either. Electrons that are re-accepted by P680 would be expected to have a higher energy level in cases of cyclic flow, unless the energy gained by quanta absorption during the first P680 passage event is effectively quenched. However, cyclic electron flow requires an existing trans-thylakoid $\mathrm{pH}$ gradient and is activated hierarchically after the capacity for protective heat dissipation is exceeded (Miyake \& Yokota 2001). It is not clear whether cyclic electron flow in PSII directly affects primary production, but its existence might enable the cells to maintain capacity for a high PSII absorption cross section under rate limiting conditions of linear ETRs. The capacity of alternative energy quenching mechanisms might therefore affect acclimation strategies in primary producers.

\section{Photosystem stoichiometry and state transitions}

Photosynthetic quantum absorption takes place in PSII and I. Electrons cycle through their reaction centres creating an electron transport loop, with energy dissipation taking place each time an electron is passed through cyclic electron flow in PSII (e.g. Cha \& Mauzerall 1992, Miyake \& Okamura 2003) and cyclic electron transport around PSI (e.g. Joliot \& Joliot 2006). During linear electron transport, both photosystems contribute equally, with $\sim 1$ photon absorbed per electron transported in each photosystem (Falkowski \& Raven 1997, 2007). Regulation of cyclic vs. linear electron transport can lead to measurable changes in primary productivity. However, since energy distribution between photosystems is plastic and can be regulated at time scales of minutes (state transition) or hours (changes in photosystem stoichiometry), the method of choice and the interpretation of results need to be carefully considered. The extent to which changes in energy production and energy quality (ATP:NADPH ratios) affect cell function and downstream energy distribution is complex (Gauthier \& Turpin 1997, Forti et al. 2003). Andrews et al. (1993) found that $\mathrm{CO}_{2}$ assimilation was not affected during a state transition event, but the absorption cross-section did change during a state transition. The cross-section of PSI can be elevated when light harvesting complexes are in state II, which results in a higher photon capture than prior to a 
state I to state II transition, and PSI is more likely to dissipate energy using cyclic electron transport around it. This leads to elevated ATP production, even when linear ETRs are maintained, since the state transition might function as a relaxation system for heat dissipation. While state transitions are thought to act as a photoprotective system, less is known about their role in energy quality regulation.

Balanced energy equivalents are required under all light quantity and quality conditions. Under low light conditions, PS stoichiometry appears to be important and dominates over state transitions as a response factor (Bailey et al. 2001). Arabidopsis mutants that lacked the regulatory unit for state transitions and PS adjustments produced $20 \%$ fewer seeds than wild types under similar conditions (Dietzel et al. 2008), reflecting an overall decrease in primary productivity. Inadequate energy supply from photosynthetic units may affect energy distribution within cells. There is evidence for example that the oxidation state of the plastoquinone pool is a key sensor for both state transitions and PS acclimation (Allen \& Pfannschmidt 2000, Quigg et al. 2006, Dietzel et al. 2008). Adjustments in PS protein turnover involves gene transcription in the chloroplast as well as in the nucleus; these are both at least partly controlled by the plastoquinone pool redox state (Fey et al. 2005a, Quigg et al. 2006). Dietzel et al. (2008) emphasised that changes in PS stoichiometry will have downstream effects on carbon metabolism, nucleotide and amino acid synthesis. Thus, regulation and acclimation of the energy capturing apparatus will in turn affect primary production and its measurement. Since fluorescence techniques for determining primary productivity assume an equal distribution of light absorbed by PSII and PSI, deviations from this due to state transitions could influence ETR estimates.

\section{PROCESSES RUNNING COUNTER TO PHOTO- SYNTHESIS IN PRIMARY PRODUCTION}

Some processes in marine primary producers run counter to photosynthetic metabolism and may confuse or complicate the interpretation of measurements. For instance, algal cells can excrete extracellular materials. Phytoplankton release considerable amounts of dissolved organic matter (DOM) in the form of polysaccharides or compounds such as dimethysulphonioproprionate (DMSP). DOM can make up 18 to $50 \%$ of the total inorganic carbon pool assimilated in e.g. coastal phytoplankton blooms (Wetz \& Wheeler 2003). Some macroalgae also produce copious amounts of polysaccharides. Depending on the techniques used, this material might be overlooked in analyses of e.g. ${ }^{14} \mathrm{C}$ assimilation or changes in biomass. Material can also be consumed or lost through mechanical damage and grazing - processes that are important for estimates of productivity through biomass accrual.

Respiratory mechanisms oxidise organic matter and, in so doing, release $\mathrm{CO}_{2}$ and (ignoring anaerobic fermentation processes) consume $\mathrm{O}_{2}$. Gas exchange measurements should thus provide estimates of net photosynthesis. In the case of ${ }^{14} \mathrm{C}$ tracer uptake, data reflect either net photosynthesis (if incubation is long enough for respiratory substrates to become labelled) or gross photosynthesis (if incubation times are short and no ${ }^{14} \mathrm{C}$-labelled material is respired) (see Williams et al. 2002 for details). On the other hand, measurements of photosynthetic ETRs based on fluorescence are theoretically indicative of gross photosynthesis. While measurements of $\mathrm{O}_{2}$ exchange in the light reflect net production, the use of $\mathrm{O}_{2}$ stable isotopes can give estimates of gross $\mathrm{O}_{2}$ evolution (Grande et al. 1989b, 1991, Luz et al. 1999, Luz \& Barkan 2000). There is a range of $\mathrm{O}_{2}$-consuming processes that contribute to the net vs. gross equation.

Some of these $\mathrm{O}_{2}$ consuming reactions are light dependent or associated with processes that occur during light exposure, and include photorespiration, Rubisco oxygenase and glycolate oxidase activities, and the Mehler-peroxidase reaction (Beardall et al. 2003, Raven \& Beardall 2005). 'Dark respiration' processes that consume $\mathrm{O}_{2}$ are driven by cytochrome oxidase and alternate oxidase activities, and chlororespiration associated with thylakoid membranes also has an associated terminal oxidase (Beardall et al. 2003). Even the rates of dark respiration can be very variable and dependent on the previous light exposure of algal cells (Beardall et al. 1994). They can also be driven by alternative demands on electrons such as nutrient availability. For example, Cabello-Pasini \& Figueroa (2005) demonstrated a strong dependence of respiratory $\mathrm{O}_{2}$ consumption, and hence of the gross photosynthesis:respiration ratio, on nitrate concentration in Ulva rigida.

\section{Alternative energy sinks and respiratory processes}

Photosynthetic and respiratory pathways are intimately coupled in all phototrophs, but more so in Cyanobacteria where these processes must also interact with nitrogen fixation. In eukaryotic cells, photosynthesis occurs in chloroplasts while respiration occurs in mitochondria. While these organelles can act autonomously, new studies are revealing interactions for efficient use of energy (ATP), reducing power (NADPH) and carbon skeletons (Beardall et al. 2003, Raven \& Beardall 2003, 2005). This involves the import of reducing equivalents by peroxisomes from both 
chloroplasts and mitochondria, while the cytoplasm acts as a medium for the flux of related metabolites.

In Cyanobacteria, photosynthetic electron transport occurs solely in thylakoids, whereas respiratory electron flow takes place both in the thylakoid and cytoplasmic membrane systems. The thylakoid membrane functions as an internal membrane system that separates the cytoplasm from the lumen. These electron transport chains intersect and partly utilize the same components in the membrane. Nitrogenase, the enzyme that fixes nitrogen in Cyanobacteria, requires an anaerobic environment. Simultaneously, photosynthesis and respiration involve the exchange of $\mathrm{O}_{2}$. Spatial separation of nitrogen fixation is thus found in species of Cyanobacteria that have heterocysts (e.g. Anabaena, Nostoc), while those with only vegetative cells rely on temporal separation of these processes (Scherer et al. 1988, Berman-Frank et al. 2003).

\section{Photoacclimation}

In phototrophs, photoacclimation can be interpreted in terms of cellular energy balance (Richardson et al. 1983). Major limitations on growth at extremely low photon fluxes $\left(\leq 1 \mu \mathrm{mol}\right.$ photons $\left.\mathrm{m}^{-2} \mathrm{~s}^{-1}\right)$ are thought to include protein turnover, charge recombination in PSII, and proton leakage and slippage (Raven et al. 2000, Quigg \& Beardall 2003, Quigg et al. 2003, 2006). These processes act synergistically, limiting rates of photosynthesis and the minimum specific growth rate. In terms of carbon balance, this indicates that any factor that increases protein concentration or the leakiness of membranes will increase maintenance respiration rates. Since a relatively constant cytoplasmic ion concentration is vital, protein turnover may be the major but variable component of maintenance costs. Energy distribution patterns are, however, affected by species-specific photoacclimation strategies: photosynthetic electron transport to carbon fixation or/and $\mathrm{O}_{2}$ production rates, cell volume adjustments, differences in elemental $(C$, $\mathrm{N}, \mathrm{P}, \mathrm{Fe}$, etc.) ratios, and changes in protein transcription efficiencies (Miller et al. 1991, Sciandra et al. 1997, Longstaff et al. 2002, Quigg \& Beardall 2003, Beer \& Axelsson 2004, Leonardos \& Geider 2004, Jakob et al. 2005, Wilhelm et al. 2006).

\section{Respiration}

Respiratory processes are necessary not only to drive biosynthetic reactions that lead to the increment of dry matter, but also to maintain cellular structures. Thus, any factor (e.g. temperature, growth rate) that increases the metabolic rate will tend to increase dark respiration rates. Maintenance respiration is the minimum energy consumption rate required to maintain the viability of microalgae. It includes processes that maintain cellular structures and gradients of ions and metabolites, and physiological adaptations that keep microalgae active in a changing environment. Maintenance respiration can be used to estimate the energy available for maintenance processes (assuming complete coupling in respiratory energy conversions). The likelihood that some of the maintenance energy requirements in the light are supplied by the direct use of photoproduced ATP rather than via dark respiration cannot be ignored, but is difficult to quantify and would have little effect on the overall energy budget (Raven \& Beardall 1981a). Maintenance respiration can most simply be determined by extrapolation of a dark respiration rate vs. growth rate curve to the zero growth rate. Dark respiration has been found to be linearly (and positively) related to growth rate in a number of microalgae (Laws \& Bannister 1980, Verity 1982, Langdon 1988, Geider \& Osborne 1989) but not in all species (Quigg \& Beardall 2003). The assumptions and/or calculations used to determine maintenance respiration rates are summarized by Quigg (2000). The paucity of measurements in microalgae reflects the difficult interpretation of dark respiration in terms of an energy budget. There continues to be uncertainty regarding the degree to which dark respiration values are related to maintenance and/or synthetic metabolic costs in unicellular phototrophs (Shuter 1979, Laws et al. 1983, Richardson et al. 1983, Geider 1992, Geider et al. 1996, Raven et al. 2000). There is even greater uncertainty when applying these same principles to macroalgae, seagrasses and higher phototrophs as energy demands for cellular structures and reproduction compete with maintenance energy demands.

\section{Protein turnover}

The cycle of protein degradation and re-synthesis is collectively referred to as protein turnover. This process has long been recognized as important in the regulation of biological systems and has several purposes including (1) regulation of enzyme activities, (2) removal of abnormal proteins, (3) adaptation to different environments by allowing changes in the relative concentrations of different proteins, and (4) a mechanism enabling microalgae to compete under a range of environmental conditions. It is also thought to be the most significant component of maintenance processes and hence of dark respiration in terms of cellular energy requirements (Penning de Vries 1975, Raven \& Beardall 1981b, Geider et al. 1996, Lambers et al. 1998, Raven et al. 2000). Other things being equal, a higher 
protein content per cell implies a higher maintenance respiration rate related to protein turnover; thus, a lowprotein cell could economize on maintenance as well as capital costs (Richardson et al. 1983). Quigg \& Beardall (2003) found that about a third of respiratory demands in the diatom Phaeodactylum tricornutum and in the chlorophyte Dunaliella tertiolecta were associated with protein turnover. Lower metabolic activity correlated well with lower protein concentrations and an associated decreased maintenance respiration rate. These results are consistent with studies proposing that species best adapted to growth at low light have lower maintenance respiration rates (Langdon 1988, Falkowski \& Raven 1997), where diatoms are reported to typically exhibit lower values than flagellates. There is, however, a trade-off between greater efficiency of respiratory processes in fast-growing species and lower specific costs of energy demanding processes (Lambers 1987, Geider \& Osborne 1989).

\section{'Slippage'}

In terms of photosynthetic energy conversion, slippage implies a less-than-theoretical stoichiometry of some energy transduction process that leads to proportionally larger reductions in photon efficiency at low rates of photon absorption (Richardson et al. 1983, Raven 1986, Quigg et al. 2006). Radmer \& Kok (1977) and Raven \& Beardall $(1981 b, 1982)$ predicted that the most important slippage reactions when considering microalgal growth at extremely low photon fluxes $(\leq 1$ umol photons $\mathrm{m}^{-2} \mathrm{~s}^{-1}$ ) were (1) the decay of the unstable intermediates ( $\mathrm{S} 2$ and $\mathrm{S} 3$ states) of the $\mathrm{O}_{2}$ evolution pathway of photosynthesis, and (2) the functioning of primary active proton porters as passive uniporters (e.g. the CF0-CF1 ATP synthetase), i.e. the 'leakage' of protons leading to the breakdown of the electrochemical gradient across the thylakoid membrane. Of these, passive proton leakage is thought to affect quantum yield most dramatically (Richardson et al. 1983, Raven 1986). In addition, Raven \& Beardall (1982) proposed that the slippage reactions would be largely 'maintenance' rather than 'growth' costs, and hence would be proportionately more significant at low energy-conversion rates. In order to reduce slippage, phototrophs may reduce the quantity of energy transducers (reaction centres) per unit of energy transmitters (light harvesting pigments), i.e. increase the size of the photosynthetic units, or they may reduce the intrinsic slippage of the transducers, or a combination of these 2 possibilities (Raven \& Beardall 1981a, 1982, Richardson et al. 1983, Raven et al. 2000, Quigg et al. 2003, 2006). An additional source of proton leakage or slippage may be the transmembrane light-harvesting pig- ment-protein complexes (Richardson et al. 1983), but the question of how thylakoid proton electrochemical gradients are maintained is yet to be elucidated (Strotmann et al. 1986, Renganathan \& Dilley 1994).

\section{Homeostasis}

Biological processes such as photosynthesis and respiration rely on intracellular $\mathrm{pH}$ homeostasis. In microalgal cells, this is achieved by the balance between the rates of proton-producing and proton-consuming reactions (which include $\mathrm{NO}_{3}{ }^{-}$and $\mathrm{SO}_{4}{ }^{2-}$ reduction, and DMSP production) and of fluxes of $\mathrm{H}^{+}$or $\mathrm{OH}^{-}$through various transporters along with passive diffusion pathways (Raven \& Smith 1974, 1976, Nimer et al. 1994). Protonation, which is critical for the biological function of many enzymes, is dependent on the $\mathrm{pH}$ balance in cells (Haussinger et al. 1988). In addition, the internal $\mathrm{pH}$ in marine photoautotrophs has to be precisely regulated, usually between 7 and 7.4, because they have a negative plasmalemma membrane potential in seawater (Nimer et al. 1999), which may lead to the passive diffusion of protons into the cytosol and alteration of the internal pH. However, this is not likely to be an issue since the inward driving force for $\mathrm{H}^{+}$is very small (19 mV; Nimer et al. 1994). Interestingly, the cytoplasmic $\mathrm{pH}$ in high-calcifying cells such as those of Emiliania huxleyi is more acidic (Nimer et al. 1994) than that measured in non-calcifying marine microalgae (Raven \& Smith 1980, Burns \& Beardall 1987) and that reported in plant cells (Raven 1980, Smith 1980).

Uptake and assimilation of $\mathrm{CO}_{2}$ can exert a dual effect on internal $\mathrm{pH}$. First, $\mathrm{CO}_{2}$ fixation by Rubisco can increase internal $\mathrm{pH}$ within the chloroplast stroma (in eukaryotes) or in the cytosol (in Cyanobacteria) by removing $\mathrm{CO}_{2}$. Many species of marine microalgae show enhanced growth at elevated $\mathrm{CO}_{2}$ concentrations (Gehl \& Colman 1985, Sültemeyer et al. 1989, Beardall et al. 2003, Raven \& Beardall 2003). However, increasing $\mathrm{CO}_{2}$ leads to a decline in $\mathrm{pH}$. Inhibition of growth of the high-calcifying cells of Emiliania huxleyi at elevated $\mathrm{CO}_{2}$ is thought to be related to their inability to generate adequate $\mathrm{OH}^{-}$to neutralize the protons produced by calcification (Nimer \& Merrett 1993) and to counteract the acidification of the cytosol resulting from the passive diffusion of $\mathrm{CO}_{2}$ at elevated ambient concentrations (Nimer et al. 1994).

\section{$\mathrm{CO}_{2}$ concentrating mechanisms can act as a major energy dissipating process}

The $\mathrm{CO}_{2}$ concentrating mechanisms (CCMs) of Cyanobacteria and algae, which are driven by photo- 
synthesis (Giordano et al. 2005), are energetically expensive, although cost-benefit analyses suggest that these energy costs can compare quite favourably with those of fixation via Rubisco following diffusive $\mathrm{CO}_{2}$ entry and the subsequent costs of photorespiration and glycolate metabolism (Beardall 1991, Raven et al. 2000, Beardall \& Giordano 2002). The CCM may thus represent a significant drain on photosynthetic electron flow, especially since CCMs may sometimes act as a 'pump and leak' system. Thus, some Cyanobacteria and some species of the eukaryote genus Nannochloropsis have been shown to exhibit very high rates of $\mathrm{HCO}_{3}{ }^{-}$transport (Salon et al. 1996, Tchernov et al. 1998). The resulting internal pools of $\mathrm{CO}_{2}$ can be so large that leakage of $\mathrm{CO}_{2}$ can be very high, with up to $\sim 90 \%$ of the $\mathrm{HCO}_{3}{ }^{-}$taken up subsequently released as $\mathrm{CO}_{2}$ (Sukenik et al. 1997). The inorganic carbon cycling resulting from this pump and leak system has been proposed to serve as a mechanism to dissipate excess light energy in cells in surface waters (Tchernov et al. 1998). The CCM may thus act as an alternative electron sink during photosynthesis.

\section{CONCLUDING REMARKS}

It is clear that there is reasonable correlation between measurements of primary productivity carried out using fluorescence, carbon assimilation and $\mathrm{O}_{2}$ exchange. There are, however, situations where these relationships break down, especially under conditions of imbalance between the availability of light to drive electron transport and the availability of inorganic carbon or nutrients to act as electron sinks. Under these circumstances, a range of processes (photorespiration, dark respiration, chlororespiration, cyclic electron flow around PSI or around PSII, and the Mehler reaction) can contribute to departures from linearity between the different measures of primary production. The more we understand the basic processes involved and the fate of electrons produced during the primary events of photosynthesis, the better able we will be to accurately measure rates of production in aquatic ecosystems.

Looking into the future, we are faced with a situation where the availability of $\mathrm{CO}_{2}$ will triple over the next century (although with the consequent $\mathrm{pH}$ shifts, the total inorganic carbon available for photosynthesis will only increase by $<10 \%$; Beardall \& Stojkovic 2006). The consequences for our ability to accurately measure primary productivity remain to be determined, although there might be some down-regulation of energy-demanding CCMs. Shifts in photosystem stoichiometry may be expected, with implications for the relationship between fluorescence and other tech- niques for the estimation of primary productivity. Excretion of materials such as transparent exopolymer particles (TEP) are also likely to increase (Engel 2002, Engel et al. 2004), making it even more important to measure extracellular components in ${ }^{14} \mathrm{C}$-based measurements of phytoplankton productivity if we are to get good estimates of net and gross production. Overall, global warming will increase stratification of surface waters, and this will result in earlier onset of nutrient limitation, with consequences for photosynthesis and productivity (see Beardall \& Stojkovic 2006). Clearly, the consequences of global change, not only for the physiology of primary producers, but also for our ability to accurately measure primary productivity, require further effort.

Acknowledgements. We thank the Batsheva de Rothschild Foundation, Bar Ilan University, the Moshe Shilo Center for Marine Biogeochemistry, and the staff of the Interuniversity Institute for funding and logistic support. This review is based on a keynote address given during the 8th International Workshop of the Group for Aquatic Primary Productivity (GAP) and the Batsheva de Rothschild Seminar on Gross and Net Primary Productivity held at the Interuniversity Institute for Marine Sciences, Eilat, Israel in April 2008.

\section{LITERATURE CITED}

Allen JF, Pfannschmidt T (2000) Balancing the two photosystems: photosynthetic electron transfer governs transcription of reaction centre genes in chloroplasts. Philos Trans R Soc Lond B 355:1351-1357

Andrews JR, Bredenkamp GJ, Baker NR (1993) Evaluation of the role of state transitions in determining the efficiency of light utilisation for $\mathrm{CO}_{2}$ assimilation in leaves. Photosynth Res 38:15-26

Arnon DI, Tang GMS (1988) Cytochrome b-559 and proton conductance in oxygenic photosynthesis. Proc Natl Acad Sci USA 85:9524-9528

Bailey S, Walters RG, Jansson S, Horton P (2001) Acclimation of Arabidopsis thaliana to the light environment: the existence of separate low light and high light responses. Planta 213:794-801

Barranguet C, Kromkamp J (2000) Estimating primary production rates from photosynthetic electron transport in estuarine microphytobenthos. Mar Ecol Prog Ser 204: $39-52$

Beardall J (1991) Effects of photon flux density on the ' $\mathrm{CO}_{2}$ concentrating mechanism' of the cyanobacterium Anabaena variabilis. J Plankton Res 13:133-141

Beardall J, Giordano M (2002) Ecological implications of microalgal and cyanobacterial CCMs and their regulation. Funct Plant Biol 29:335-347

Beardall J, Stojkovic S (2006) Microalgae under global environmental change: implications for growth and productivity, populations and trophic flow. ScienceAsia 32(s1): 001-010

Beardall J, Burger-Wiersma T, Rykeboer M, Sukenik A, Lemoalle J, Dubinsky Z, Fontvielle D (1994) Studies on enhanced post-illumination respiration in microalgae. J Plankton Res 16:1401-1410

Beardall J, Quigg AS, Raven JA (2003) Oxygen consumption: 
photorespiration and chlororespiration. In: Larkum $\mathrm{A}_{\text {, }}$ Raven JA, Douglas S (eds) Photosynthesis in algae. Advances in photosynthesis and respiration. Kluwer Academic Publishers, Dordrecht, p 157-181

Beer S, Axelsson L (2004) Limitations in the use of PAM fluorometry for measuring photosynthetic rates of macroalgae at high irradiances. Eur J Phycol 39:1-7

Beer S, Vilenkin B, Weill A, Veste M, Susel L, Eshell A (1998) Measuring photosynthetic rates in seagrasses by pulse amplitude modulated (PAM) fluorometry. Mar Ecol Prog Ser 174:293-300

Bender M, Orchardo J, Dickson M, Barber R, Lindley S (1999) In vitro $\mathrm{O}_{2}$ fluxes compared with ${ }^{14} \mathrm{C}$ production and other rate terms during the JGOFS Equatorial Pacific experiment. Deep-Sea Res I 46:637-654

Berman-Frank I, Lundgren P, Falkowski PG (2003) Nitrogen fixation and photosynthetic oxygen evolution in Cyanobacteria. Res Microbiol 154:157-164

Burns BD, Beardall J (1987) Utilization of inorganic carbon by marine microalgae. J Exp Mar Biol Ecol 107:75-86

> Cabello-Pasini A, Figueroa FL (2005) Effect of nitrate concentration on the relationship between photosynthetic oxygen evolution and electron transport rate in Ulva rigida (Chlorophyta). J Phycol 41:1169-1177

Carr H, Björk M (2003) A methodological comparison of photosynthetic oxygen evolution and estimated electron transport rate in tropical Ulva (Chlorophyceae) species under different light and inorganic carbon conditions. J Phycol 39:1125-1131

- Cha Y, Mauzerall D (1992) Energy storage of linear and cyclic electron flows in photosynthesis. Plant Physiol 100: 1869-1877

Dietzel L, Braeutigam K, Pfannschmidt T (2008) Photosynthetic acclimation: state transitions and adjustment of photosystem stoichiometry - functional relationships between short-term and long-term light quality acclimation in plants. FEBS J 275:1080-1088

Dubinsky Z, Feitelson J, Mauzerall D (1998) Listening to phytoplankton: measuring biomass and photosynthesis by photoacoustics. J Phycol 34:888-892

> Engel A (2002) Direct relationship between $\mathrm{CO}_{2}$ uptake and transparent exopolymer particles production in natural phytoplankton. J Plankton Res 24:49-53

Engel A, Thoms S, Riebesell U, Rochelle-Newall E, Zondervan I (2004) Polysaccharide aggregation as a potential sink for marine dissolved organic carbon. Nature 428: 929-931

Falkowski PG, Raven JA (1997) Aquatic photosynthesis. Blackwell Science, Capital City Press, Washington, DC

Falkowski PG, Raven JA (2007) Aquatic photosynthesis, 2nd edn. Princeton University Press, Princeton, NJ

> Fey V, Wagner R, Bräutigam K, Pfannschmidt T (2005a) Photosynthetic redox control of nuclear gene expression. J Exp Bot 56:1491-1498

- Figueroa FL, Conde-Álvarez R, Gómez I (2003) Relations between electron transport rates determined by pulse amplitude modulated chlorophyll fluorescence and oxygen evolution in macroalgae under different light conditions. Photosynth Res 75:259-275

Forti G, Furia A, Bombelli P, Finazzi G (2003) In vivo changes of the oxidation-reduction state of NADP and of the ATP/ADP cellular ratio linked to the photosynthetic activity in Chlamydomonas reinhardtii. Plant Physiol 132:1464-1474

Franklin L, Badger MR (2001) A comparison of photosynthetic electron transport rates in macroalgae measured by pulse amplitude modulated chlorophyll fluorometry and mass spectrometry. J Phycol 37:756-767

Gauthier DA, Turpin DH (1997) Interactions between inorganic phosphate (Pi) assimilation, photosynthesis and respiration in the Pi-limited green alga Selenastrum minutum. Plant Cell Environ 20:12-24

Gehl KA, Colman B (1985) Effect of external pH on the internal $\mathrm{pH}$ of Chlorella saccharophila. Plant Physiol 77: 917-921

Geider RJ (1992) Respiration: taxation without representation? In: Falkowski PG, Woodhead AD (eds) Primary productivity and biogeochemical cycles in the sea. Plenum Press, New York, p 333-360

Geider RJ, Osborne BA (1989) Respiration and microalgal growth: a review of the quantitative relationship between dark respiration and growth. New Phytol 112:327-394

Geider RJ, MacIntyre HL, Kana TM (1996) A dynamic model of photoadaptation in phytoplankton. Limnol Oceanogr 41:1-15

Giordano M, Beardall J, Raven JA (2005) $\mathrm{CO}_{2}$ concentrating mechanisms in algae: mechanisms, environmental modulation and evolution. Annu Rev Plant Biol 56:99-131

Gordillo FJL, Jiminiz C, Chavarria J, Niell FX (2001) Photosynthetic acclimation to photon irradiance and its relation to chlorophyll fluorescence and carbon assimilation in the halotolerant green alga Dunaliella viridis. Photosynth Res 68:225-235

> Grande KD, Williams PJLeB, Marra J, Purdie DA, Heinemann K, Eppley RW, Bender ML (1989a) Primary production in the North Pacific gyre: a comparison of rates determined by the ${ }^{14} \mathrm{C}_{1} \mathrm{O}_{2}$ concentration and ${ }^{18} \mathrm{O}$ methods. Deep-Sea Res A 36:1621-1634

> Grande KD, Marra J, Langdon C, Heinemann K, Bender ML (1989b) Rates of respiration in the light measured in marine phytoplankton using an ${ }^{18} \mathrm{O}$ isotope-labelling technique. J Exp Mar Biol Ecol 129:95-120

Grande KD, Bender M, Irwin B, Platt T (1991) A comparison of net and gross rates of oxygen production as a function of light intensity in some natural plankton populations and in a Synechococcus culture. J Plankton Res 13:1-16

Hanelt D, Nultsch W (1995) Field studies of photoinhibition show non-correlations between oxygen and fluorescence measurements in the Arctic red alga Palmaria palmata. J Plant Physiol 145:31-38

Haussinger D, Gerok W, Guder W, Silbernagl S, Sies H (1988) Why pH homeostasis. In: Haussinger D (ed) pH homeostasis mechanisms and control. Academic Press, London, p 1-4

Herbert SK, Han T, Vogelmann TC (2000) New applications of photoacoustics to the study of photosynthesis. Photosynth Res 66:13-31

Jakob T, Schreiber U, Kirchesch V, Langner U, Wilhelm C (2005) Estimation of chlorophyll content and daily primary production of the major algal groups by means of multiwavelength-excitation PAM chlorophyll fluorometry: performance and methodological limits. Photosynth Res 83:343-361

> Johnston AM, Raven JA (1986) The analysis of photosynthesis in air and water of Ascophyllum nodosum (L.) Le Jol. Oecologia 69:288-295

Johnston AM, Raven JA (1990) Effects of culture in high $\mathrm{CO}_{2}$ on the photosynthetic physiology of Fucus serratus. $\mathrm{Br}$ Phycol J 25:75-82

Joliot P, Joliot A (2006) Cyclic electron flow in C3 plants. BBABioenergetics 1757:362-368

Kolber ZS, Prasil O, Falkowski PG (1998) Measurements of variable chlorophyll fluorescence using fast repetition rate techniques: defining methodology and experimental pro- 
tocols. Biochim Biophys Acta 1367:88-106

Krieger A, Moya I, Weiss E (1992) Energy-dependent quenching of chlorophyll a fluorescence and picosecond-relaxation kinetics in thylakoid membranes and photosystem II preparations. Biochim Biophys Acta 1144:411-418

Kroon BMA, Thoms S (2006) From electron to biomass: a mechanistic model to describe phytoplankton photosynthesis and steady-state growth rates. J Phycol 42:593-609

Kruk J, Strzalka K (2001) Redox changes of cytochrome $b_{559}$ in the presence of plastoquinones. J Biol Chem 276:86-91

Lambers H (1987) Growth, respiration, exudation and symbiotic associations: the fate of carbon translocated to the roots. In: Gregory PJ, Lake JV, Rose DA (eds) Root development and function. SEB Seminar series 30. Cambridge University Press, Cambridge, p 125-145

Lambers H, Chapin FS III, Pons TL (1998) The role of respiration in plant carbon balance. In: Plant physiological ecology. Springer-Verlag, New York, p 122-135

Langdon C (1988) On the cause of interspecific differences in the growth-irradiance relationship for phytoplankton. II. A general review. J Plankton Res 10:1291-1312

Laws EA, Bannister TT (1980) Nutrient- and light-limited growth of Thalassiosira fluviatilis in continuous culture, with implications for phytoplankton growth in the ocean. Limnol Oceanogr 25:457-473

Laws EA, Redalje DG, Karl DM, Chalup MS (1983) A theoretical and experimental examination of the predictions of two recent models of phytoplankton growth. J Theor Biol 105:469-491

Laws EA, Landry MR, Barber RT, Campbell L, Dickson ML, Marra J (2000) Carbon cycling in primary production bottle incubations: inferences from grazing experiments and photosynthetic studies using ${ }^{14} \mathrm{C}$ and ${ }^{18} \mathrm{O}$ in the Arabian Sea. Deep-Sea Res II 47:1339-1352

> Leonardos N, Geider R (2004) Effects of nitrate:phosphate supply ratio and irradiance on the C:N:P stoichiometry of Chaetoceros muelleri. Eur J Phycol 39:173-180

Longhurst A, Sathyendranath S, Platt T, Caverhill C (1995) As estimate of global primary production in the ocean from satellite radiometer data. J Plankton Res 17:1245-1271

Longstaff BJ, Kildea T, Runcie JW, Cheshire A and others (2002) An in situ study of photosynthetic oxygen exchange and electron transport rate in the marine macroalga Ulva lactuca (Chlorophyta). Photosynth Res 74:281-293

Luz B, Barkan E, Bender ML, Thiemens MH, Boering KA (1999) Triple-isotope composition of atmospheric oxygen as a tracer of biosphere productivity. Nature 400:547-550

Luz B, Barkan E (2000) Assessment of oceanic productivity with triple-isotope composition of dissolved oxygen. Science 288:2028-2031

Miller HL, Dunton KH (2007) Stable isotope $\left({ }^{13} \mathrm{C}\right)$ and $\mathrm{O}_{2}$ micro-optode alternatives for measuring photosynthesis in seaweeds. Mar Ecol Prog Ser 329:85-97

Miller AG, Espie GS, Canvin DT (1991) The effects of inorganic carbon and oxygen on fluorescence in the cyanobacterium Synechococcus Utex 625. Can J Bot 69: $1151-1160$

Miyake C, Okamura M (2003) Cyclic electron flow within PSII protects PSII from its photoinhibition in thylakoid membranes from spinach chloroplasts. Plant Cell Physiol 44:457-462

- Miyake C, Yokota A (2001) Cyclic flow of electrons within PSII in thylakoid membranes. Plant Cell Physiol 42: 508-515

Nimer NA, Merrett MJ (1993) Calcification rate in Emiliania huxleyi Lohmann in response to light, nitrate and availability of inorganic carbon. New Phytol 123:673-677
Nimer NA, Brownlee C, Merrett MJ (1999) Extracellular carbonic anhydrase facilitates carbon dioxide availability for photosynthesis in the marine dinoflagellate Prorocentrum micans. Plant Physiol 120:105-112

> Nimer NA, Brownlee C, Merrett MJ (1994) Carbon dioxide availability, intracellular $\mathrm{pH}$ and growth rate of the coccolithophore Emiliania huxleyi. Mar Ecol Prog Ser 109: 257-262

Penning de Vries FWT (1975) The cost of maintenance processes in plant cells. Ann Bot (Lond) 39:77-92

> Pinchasov Y, Porat R, Zur B, Dubinsky Z (2007) Photoacoustics: a novel tool for the determination of photosynthetic energy storage efficiency in phytoplankton. Hydrobiologia 579:251-256

Prasil O, Zbigniew K, Berry JA, Falkowski PG (1996) Cyclic electron flow around photosystem II in vivo. Photosynth Res 48:395-410

> Quay PD, Emerson S, Wilbur DO, Stump C (1993) The $\delta^{18} \mathrm{O}$ of dissolved $\mathrm{O}_{2}$ in the surface waters of the Subarctic Pacific: a tracer of biological productivity. J Geophys Res 98(C5):8447-8458

Quigg A (2000) A study of physiological features determining the capacity of two marine microalgae to grow at low irradiance. PhD thesis, Monash University, Victoria

Quigg A, Kevekordes K. Phillips JA (2008) Ecophysiological status of nine species of macroalgae and seagrasses in Moreton Bay, Queensland, Australia. In: Davie PJF, Phillips JA (eds) Proc 13th Int Mar Biol Workshop, The marine fauna and flora of Moreton Bay, Queensland. Memoirs of the Queensland Museum-Nature 54: 391-403

> Quigg A, Beardall J (2003) Protein turnover in relation to maintenance metabolism at low photon flux in two marine microalgae. Plant Cell Environ 26:693-703

Quigg A, Beardall J, Wydrzynski T (2003) Photoacclimation involves modulation of the photosynthetic oxygen-evolving reactions in Dunaliella tertiolecta and Phaeodactylum tricornutum. Funct Plant Biol 30:301-308

Quigg A, Kevekordes K, Raven JA, Beardall J (2006) Limitations on microalgal growth at very low photon flux densities: the role of energy slippage and $\mathrm{H}^{+}$leakage. Photosynth Res 88:299-310

Radmer R, Kok B (1977) Light energy conversion in photosynthesis. In: Trebst A, Avron M (eds) Encyclopedia of plant physiology, New Series, Vol 5. Springer-Verlag, Berlin, p 125-135

Raven JA (1980) Nutrient transport in microalgae. Adv Microb Physiol 21:1357-1369

Raven JA (1986) Physiological consequences of extremely small size for autotrophic organisms in the sea. In: Platt T, Li WKW (eds) Photosynthetic picoplankton. Can Bull Fish Aquat Sci 214:1-70

Raven JA, Beardall J (2003) $\mathrm{CO}_{2}$ acquisition mechanisms in algae: carbon dioxide diffusion and carbon dioxide concentrating mechanisms. In: Larkum A, Raven JA, Douglas $\mathrm{S}$ (eds) Photosynthesis in algae. Advances in photosynthesis and respiration. Kluwer Academic Publishers, Dordrecht, p 225-244

Raven JA, Beardall J (1981a) Respiration and photorespiration. Can Bull Fish Aquat Sci 210:55-82

Raven JA, Beardall J (1981b) The intrinsic permeability of biological membranes to $\mathrm{H}^{+}$: significance for the efficiency of low rates of energy transformation. FEMS Microbiol Lett 10:1-5

Raven JA, Beardall J (1982) The lower limit of photon fluence rate for phototrophic growth: the significance of 'slippage' reactions. Plant Cell Environ 5:117-124

Raven JA, Beardall J (2005) Respiration in aquatic pho- 
tolithotrophs. In: del Giorgio PA, Williams PJLeB (eds) Respiration in aquatic ecosystems. Oxford University Press, Oxford, p 36-46

Raven JA, Smith FA (1974) Significance of hydrogen ion transport in plant cells. Can J Bot 52:1035-1048

Raven JA, Smith FA (1976) Cytoplasmic pH regulation and electrogenic $\mathrm{H}^{+}$extrusion. Curr Adv Plant Sci 8:649-659

Raven JA, Smith FA (1980) lntracellular pH regulation in the giant-celled marine alga Chaetomorpha darwinii. J Exp Bot 31:1357-1369

Raven JA, Kübler JE, Beardall J (2000) Put out the light, and then put out the light. J Mar Biol Assoc UK 80:1-25

Renganathan M, Dilley RA (1994) Evidence that the intrinsic membrane protein LHCII in thylakoids is necessary for maintaining localised $\Delta \mu_{\mathrm{H}+}$ energy coupling. J Bioenerg Biomembr 26:117-125

Richardson J, Beardall J, Raven JA (1983) Adaptation of unicellular algae to irradiance: an analysis of strategies. New Phytol 93:157-191

Salon C, Mir NA, Canvin DT (1996) Influx and efflux of inorganic carbon in Synechococcus UTEX 625. Plant Cell Environ 19:247-259

Scherer S, Almon H, Boger P (1988) Interaction of photosynthesis, respiration and nitrogen fixation in Cyanobacteria. Photosynth Res 15:95-114

Sciandra A, Gostan J, Collos Y, Descolas-Gros C and others (1997) Growth-compensating phenomena in continuous cultures of Dunaliella tertiolecta limited simultaneously by light and nitrate. Limnol Oceanogr 42:1325-1339

Shuter B (1979) A model of physiological adaptation in unicellular algae. J Theor Biol 78:519-552

Silva J, Santos R (2004) Can chlorophyll fluorescence be used to estimate photosynthetic production in the seagrass Zostera noltii? J Exp Mar Biol Ecol 307:207-216

Smith FA (1980) Comparison of the effects of ammonia and methylamine on chloride transport and intracellular $\mathrm{pH}$ in Chara corallina. J Exp Bot 31:597-606

Editorial responsibility: Ilana Berman-Frank, Ramat Gan, Israel
Steeman Nielsen E (1952) The use of radioactive carbon (C14) for measuring organic production in the sea. J Cons Int Explor Mer 18:117-140

Strotmann H, Kiefer K, Altvater-Mackensen R (1986) Equilibration of the ATPase reaction of chloroplasts at transition from strong light to weak light. Biochim Biophys Acta 850:90-96

Sukenik A, Tchernov D, Kaplan A, Lubian LM, Livne A (1997) Uptake, efflux, and photosynthetic utilization of inorganic carbon by the marine eustigmatophyte Nannochloropsis sp. J Phycol 33:969-974

Sültemeyer DF, Miller AG, Espie GS, Fock HP, Canvin DT (1989) Active $\mathrm{CO}_{2}$ transport by the green alga Chlamydomonas reinhardtii. Plant Physiol 89:1213-1219

Tchernov D, Hassidim M, Vardi A, Luz B, Sukenik A, Reinhold L, Kaplan A (1998) Photosynthesizing marine microorganisms can constitute a source of $\mathrm{CO}_{2}$ rather than a sink. Can J Bot 76:949-953

Thomas DN, Wiencke C (1991) Photosynthesis, dark respiration and light independent carbon fixation of endemic Antarctic macroalgae. Polar Biol 11:329-337

- Verity PG (1982) Effects of temperature, irradiance, and daylength on the marine diatom Leptocylindrus danicus Cleve. III. Dark respiration. J Exp Mar Biol Ecol 60: 197-207

Wetz MS, Wheeler PA (2003) Production and partitioning of organic matter during simulated phytoplankton blooms. Limnol Oceanogr 48:1808-1817

- Wilhelm C, Büchel C, Fisahn J, Goss R and others (2006) The regulation of carbon and nutrient assimilation in diatoms is significantly different from green algae. Protist 157:91-124

Williams PJLeB (1993) On the definition of plankton production terms. ICES Mar Sci Symp 197:9-19

Williams PJLeB, Thomas DN, Reynolds CS (2002) Phytoplankton productivity: carbon assimilation in marine and freshwater ecology. Wiley-Blackwell, Oxford

Submitted: December 10, 2008; Accepted: March 28, 2009

Proofs received from author(s): June 8, 2009 